\title{
Boyhood and Belonging
}

\author{
Michael R. M. Ward and Thomas Thurnell-Read
}

\begin{abstract}
This special issue of Boyhood Studies considers how a group of international scholars have engaged with the concepts of boyhood and belonging as a complex personal and powerful process. In different ways, the authors highlight how belonging is an ongoing negotiation within one's surroundings. The international research presented here compels us to conceptualize belonging and boyhood as something that is not only infused with individuals and collective histories, but also interwoven within different conceptions of place and space. These places and spaces are experienced in multiple ways within different social contexts. We contend that this special issue is positioned at an important time in studies of boys and young men. As boys and young men experience their transition into adulthood with increased precarity, it is time we take theories of boyhood and belonging seriously. These theories can open up new spaces and provide critical insights into young lives.
\end{abstract}

Keywords: belonging, boyhood, boys, place, space, young men

How young people negotiate a sense of belonging in their everyday lives is an increasingly emerging area of scholarship. In the field of youth studies over the past decade, we have seen a growing emphasis on how young people respond to social changes associated with modernity and globalization, which, to varying degrees, contribute to both social cohesion and fragmentation (Butcher and Harris 2010; Habib and Ward 2019a, 2019b). A backdrop of social, cultural, and economic upheavals around the globe has seen gender and youth identity and culture being reconfigured in myriad ways (Nayak and Kehily 2013). Of particular salience in studies of boys and young men is their lived experience within everyday multicultural societies in an increasingly globalized world. We suggest boys and young men are negotiating various narratives concerning the multiple roles they play in society as they come to terms with the politics of belonging. Further still, diverse empirical studies of the spatial contexts through which boys and young men navigate both the spectacular and ordinary moments of their lives help illuminate the processes of (dis)connection and (un)becoming by which they attempt, and sometimes fail, to achieve recognition and belonging. In this paper, we outline some of our key concerns and summaries the contributions made by the authors within this special issue. 


\section{Competing Discourses}

Since the 1990s, there has appeared to be an increasing anxiety in the Global North about the position of boys and young men (Morgan 2006; Robb et al. 2015; Roberts 2014; Tarrant et al. 2015; Ward et al. 2017). These concerns have centered on a range of issues including boys' supposed educational "underachievement" (when compared to that of girls), high rates of suicide, and poor mental health among young men; a lack of male role models (Robb et al. 2015), and boys' involvement in offending and antisocial behavior. Similar concerns about these issues are also emerging in a range of other countries around the world (e.g., Edström et al. 2015; Kulkarni and Jain 2018). These problems are often framed as outcomes of a "war" on boys (Hoff Sommers 2013) or a "crisis" of masculinity (Morgan 2006; Roberts 2014).

However, this discourse is far from novel and has a much longer history than the current "crisis" suggests (Connell 1995; Greig 2012). Other studies illustrate that the loss of well-paid, secure, industrial and manufacturing jobs, which has deeply affected the towns and cities that relied on these industries, overtly disadvantages some boys and young men over others (McDowell 2012; Nayak 2006; Ward 2015, 2019). Although the generic categories of "men" and "boys" are often used in policy and cultural commentaries, it is in reality young, marginalized men living in stigmatized places who most embody this anxiety (Morris 2012; Ward 2015; Walker and Roberts 2018). While place and belonging are often acknowledged implicitly in these narratives, they are rarely examined as a key factor in shaping boys and young men's lives and future opportunities. In this special issue, we address this notable absence by assembling empirical research from established and emerging scholars to foster an international focus of how boys and young men construct their identities in terms of belonging. In the next section of this paper we define the concept of belonging and its connections to boyhood, before moving to outline the articles which make up this special issue.

\section{Defining Belonging and Boyhood}

According to Hernán Cuervo and Johanna Wyn (2017: 2), "the concept of belonging is often implicit but under-theorized in discussions of place, space and young people." This international collection draws on interdisciplinary 
perspectives of space and place in order to investigate boys and young men's sense of identities and belongings. The issue aims to enhance our understanding of boys and young men's identity practices as they negotiate a sense of belonging relevant to their local and national contexts. The authors in this special issue illustrate how boys and young men "construct meaningful identities for themselves" (Habib and Ward 2019a: 2) through their conceptions of belonging, their investment in (or rejection of) peer cultures, and how these are heavily influenced by relationships with "territories" and places. Through providing empirical case studies, this special issue considers the diversity of boys and young men's identities and experiences at a local, national, and global level. What is explored is the manner in which the practices, discourses and ethos of particular locales, spaces and institutions might shape how boys and young men see themselves and others around them. Belonging emerges from this as an important but contingent and, for some, scarce, resource. More than a mere feeling for fleeting emotion, belonging lays at the heart of understanding the lived experience of coming of age in gendered space and time.

In exploring how boys and young men come to belong, we see various conceptual overlaps with the literature on contemporary theorising of masculinities as boys and young men come to understand their positions in rapidly changing and increasingly fragmented societies. Some scholars have argued that men are becoming much more fluid in their interactions with each other and have moved away from hegemonic ideals of masculinity which inculcated strict hierarchies of competition and dominance (Connell and Messerschmidt 2005; Jóhannsdóttir and Gíslason 2018; Roberts 2013). These interactions include more openness, showing emotions, physically touching other men, decreased homophobia, and more open sexual practices that deviate from traditional heterosexual scripts. However, others have suggested these changes are overstated, given the privileged position men occupy in society and that large amounts of gender-based violence are still attributed to men (Messner et al. 2015). What we should therefore perhaps be thinking about instead is a "hybridized" masculinity (Bridges and Pascoe 2014) occurring, coupled with an increasing conceptual and empirical sensitivity to the changing ways in which boys and young men perform and experience friendships, relationships, and both physical and emotional intimacies across the life course (Thurnell-Read 2012). While some men may have indeed begun to include aspects of femininity and less traditional masculine practices in their performances of self and their interactions with others, this does not necessarily mean greater gender equality and may have little or no 
impact in terms of challenge deep-seated inequality between men and women and between men of different classes, ethnicities, and localities. Indeed, the complexity of intersections of gender, class, sexuality, and race preclude the possibility of some sort of linear "progress" from less to greater inclusivity. The structures of inequality are still there under this somewhere superficial change or have not impacted all men in the same way across the global (Kulkarni and Jain 2018).

Some scholars in this emerging field theorize the nexus of boyhood and identities and belongings as connected to various self-expressions (see Cominos et al. 2019; Wignall 2019; Ward 2019). Others illustrate what it means for boys and young men to experience transitions, consumerism, displacements, and mobilities (see Marchbank and Myrdahl 2019; Picton and Banfield 2019). Mindful of these issues, this collection draws on research in the Global North and Global South, the urban and the rural, the public and the private, showcasing key sites and communities that play a role in boys and young men's lives. These include educational institutions, bathrooms, places of sexual freedom, tourist spaces, the street, and charity organizations and therefore represent spaces that are, by degrees, more or less formal, commercialized, and culturally visible. In many if not all of these spaces, freedom to express and experiment with selfhood is tempered by the constraints of both gender role expectations and socioeconomic inequality and precarity. Further still, a focus on belonging allows understanding of the experience of boyhood and emerging masculinity to be traced through and across work, education, and leisure without prioritizing one site over another.

We hope the readers of this special issue will find themselves undertaking an international journey alongside the authors of the chapters and their research participants. The individuals we include and the diversity of the places they inhabit reveal how identity construction is closely tied to conventional expectations of boyhood and masculinity, traditions, and even stereotypes that sometimes stifle ways of being and belonging. We argue that while there are huge structural factors at play, the boys and young men presented are astute in the ways they resist and challenge assumptions and obstacles that champion their energy, creativity, and sense of social justice. Likewise, though varied in their empirical approaches and contexts, all the articles share a methodological interest in hearing firsthand the voices of boys and young men while retaining a necessary sensitivity to the power differentials that are invariably present during qualitative social research (Thurnell-Read 2016). Consequently, we suggest that belonging offers an important analytical "lens" through which to make explicit the way youth 
as a social object is constructed, and lived out, relationally through dynamic processes of inclusion and exclusion (Cuervo and Wyn 2014; Farrugia and Wood 2017; Ward and Habib 2019a).

\section{This Issue}

In our first article, Elias Alexander explores how young, gay men in Seoul, South Korea, navigate a sexual identity that lies on the periphery of culturally understood and politically acceptable discourses. Drawing on ethnographic data, Alexander illustrates how gay districts exist as bastions of open selfexpression, providing a sense of belonging in a restrictive societal context. Through direct ethnographic engagement this work analyzes how Chongro, one of Seoul's gay districts, reinforces identity to create a sense of belonging against a backdrop of urban development and social change. Alexander shows how these places help formulate relationships that affirm young gay men's understanding of self, community, and belonging.

Developing the theme of community belonging, Khawla Badwan and Samantha Wilkinson, in the first of two articles focusing on belonging at universities, investigate how young men (aged 18-25) talk about, and belong to, places they inhabit in Manchester, UK. Drawing on data from 22 questionnaire respondents and three interview participants, findings reveal that while young men embrace liquid understandings of place, they express tensions between "insiders" and "outsiders." While universities appear to be significant places for young people, only 50 percent of participants reported a feeling of belonging to university communities. This article suggests recommendations for universities to ensure students feel they can open up to staff, in order to feel part of a "learning community" - a key theme of the UK National Student Survey and a central tenant in the managerial strategy of many universities (see Waller et al. 2018).

In our second of two articles that concentrate on the role of belonging in higher education, Vikki Trowler and colleagues identify that there is somewhat of a moral panic about the relative paucity of men in higher education in many countries. However, they suggest that on closer examination, just like the "at risk" discourse we outlined earlier, it does not impact all men in the same way. The experiences of marginalized young men who do attend university is mediated by their underrepresentation, as well as constructions of masculinity as a system or at individual/group level. Understanding the latter can help to ameliorate the effects of the former. 
In our fourth article, Sinead Gormally's explores the tacit endorsement of youth male gang members engaging in "race"-based conflict to gain localized levels of power in "Dixonvale," Scotland. Gormally examines the importance of belonging to an "in-group" for these young men via their connectedness to the broader residents and through cultural essentialism toward a Roma "out-group." The young, male gang members, drawing on what they perceive to be their role, adopt physical and symbolic strategies to assert their control over their space and to concretize their sense of belonging with the wider community in-group. In considering how a group of young, male gang members find connection, commonality and belonging, Gormally powerfully shows how a hardening of self-image occurs through an othering process against those deemed inferior to them.

In an article that looks at how boys and young men with intersex variation hypospadias navigate the spatial belonging of bathrooms, Celeste Orr investigates how sex-segregated bathrooms negatively impact trans, genderqueer, nonbinary, queer, and gender-nonconforming people. To begin broadening this conversation, this article focuses on the medical management of boys with the intersex variation hypospadias and demonstrates that anxieties around bathrooms extend beyond the bathroom walls—into surgical theaters - and are not simply a trans or queer issue. Orr illustrates how anxieties about bathrooms and hegemonic urinary masculine behavior inform the violent medical maltreatment of intersex boys with hypospadias; Orr argues these boys are subjected to shaming, disabling, and invasive procedures in the hope that they will reinforce compulsory dyadism and able-bodiedness, as well as exhibit hegemonic heteromasculine behaviors, namely standing to urinate. The article shows how bathroom and urination become sites of pain and trauma for boys who have experienced discriminatory, gratuitous surgical interventions. In turn, these boys' sense of masculine belonging-in terms of both identity and spatial belonging — are undermined or destroyed.

Moving to the beaches of Thailand, our sixth article, by Tiffany Pollock, details the complex positionality of the young men who migrant from within Thailand and other parts of Southeast Asia to work as fire dancers in Thai tourist resorts. While inhabiting a role that offers them employment, freedom and excitement, the young men must still negotiate their possible stigmatization and economic and cultural exploitation. Here, understanding the embodied and sensory experiences and strategies of male fire dancers sheds light on the complex performance of masculinity and ethnicity, as well as the processes by which the vagaries of international tourism manifest in the lives, and worked upon the bodies, of these young men. 
In the final article, Ross Wignall draws on ethnographic research in a Young Men's Christian Association (YMCA) in England to explore how marginalized, white, working-class boys develop a sense of emergent manhood. It is through the interactions of these boys with their YMCA instructors, that we see how attitudes to gender and responsibility intersect with wider inequalities of aspiration and opportunity, which are rooted in both their attachment to place and their desire to navigate competing expectations and divided loyalties. As with all the articles across the special issue, we see here how belonging provides an analytical "way in" to understanding the lived experiences of boys and young men who are often experiencing precarious lives.

MichaEl R. M. WARD is Senior Lecturer in Social Sciences at Swansea University, UK. His work centers on the performance of working-class masculinities within and beyond educational institutions. He is the author of the award-winning book From Labouring to Learning: Working-Class Masculinities, Education and De-industrialization (2015) and editor of Boyhood Studies: An Interdisciplinary Journal. Email: m.r.m.ward@swansea.ac.uk.

ThOMAS ThURNELL-READ is Senior Lecturer at Loughborough University, UK. Since January 2016 he has been a member of the Editorial Board for the journal Sociology, having previously been an Associate Board member since 2013, and also sits on the Editorial Advisory Board of Leisure Studies and is an Associate Editor of Annals of Tourism Research. He is the editor of Drinking Dilemmas: Space, Culture and Identity (2015) and founding member of the British Sociological Association's Alcohol Study Group. Email: t.thurnell-read@lboro.ac.uk

\section{References}

Bridges, Tristan, and C. J. Pascoe. 2014. "Hybrid Masculinities: New Directions in the Sociology of Men and Masculinities." Sociology Compass 8 (3): 246258.

Butcher, Melissa, and Anita Harris. 2010. "Pedestrian Crossings: Young People and Everyday Multiculturalism." Journal of Intercultural Studies 31 (5): 449453.

Connell, Raewyn W. 1995. Masculinities. Cambridge: Polity. 
Connell, Raewyn W, and James. W. Messerschmidt. 2005. "Hegemonic Masculinity Rethinking the Concept." Gender and Society 19 (6): 829-859. Cominos, Naya, David Caldwell, and Katie Gloede. 2019. "Brotherhood and Belonging: Creating Pedagogic Spaces for Positive Discourses of Aboriginal Youth." In Habib and Ward 2019b: 92-108.

Cuervo, Hernán, and Johanna Wyn. 2014. "Reflections on the Use of Spatial and Relational Metaphors in Youth Studies." Journal of Youth Studies 17 (7): 901915.

Edström, Jerker, Alexa Hassink, Thea Shahrokh, and Erin Stern, eds. 2015. Engendering Men: A Collaborative Review of Evidence on Men and Boys in Social Change and Gender Equality. Institute of Development Studies, PromundoUS, and Sonke Gender Justice.

Farrugia, David, and Bronwyn E. Wood. 2017. “Editorial.” Young 25 (3): 209218.

Greig, Christopher J. 2012. "Boys Underachievement in Schools, in Historical Perspective: Exploring Masculinity and Schooling in the Post-war Era 19451960 in Ontario." In Canadian Men and Masculinities: Historical and Contemporary Perspectives, ed. Christopher Greig and Wayne J. Martino, 99115. Toronto: Canadian Scholars' Press.

Habib, Sadia, and Michael R. M. Ward, eds. 2019a. Identities, Youth and Belonging: International Perspectives. London: Palgrave Macmillan.

Habib, Sadia, and Michael R. M. Ward, eds. 2019b. Youth, Place and Theories of Belonging. London: Routledge.

Hoff Sommers, Christina. 2013. The War Against Boys: How Misguided Policies Are Harming Our Young Men. 2nd ed. New York: Simon \& Schuster. Jóhannsdóttir, Ásta, and Ingólfur V. Gíslason. 2018. "Young Icelandic Men’s Perception of Masculinities." Journal of Men's Studies 26 (1): 3-19. Kulkarni Mangesh, and Rimjhim Jain, eds. 2018. An Exploration of Global Masculinities. London: Routledge.

Marchbank, Jennifer, and Tiffany Muller Myrdahl. 2019. "Queering Timmies: Theorising LGBTQ Youth Claiming and Making Space in Surrey, BC, Canada." In Habib and Ward 2019b: 39-50.

McDowell, Linda . 2012. "Post-crisis, Post-Ford and Post-gender? Youth Identities in an Era of Austerity." Journal of Youth Studies 15 (5): 573-590. Messner, Michael A., Max A. Greenberg, and Tal Peretz. 2015. Some Men: Feminist Allies in the Movement to End Violence against Women. Oxford: Oxford University Press.

Morgan, David. 2006. "The Crisis in Masculinity." In The Handbook of Gender and Women's Studies, ed. Kathy Davis, Mary Evans, and Judith Lorber, 109124. London: Sage.

Morris, Edward. 2012. Learning the Hard Way: Masculinity, Place, and the Gender Gap in Education. New Brunswick, NJ: Rutgers University Press. 
Nayak, Anoop. 2006. "Displaced Masculinities: Chavs, Youth and Class in the Post-industrial City." Sociology 40 (5): 813-831.

Nayak, Anoop, and Mary Jayne Kehily. 2013. Gender, Youth and Culture: Young Masculinities and Femininities. London: Macmillan International Higher Education.

Picton, Fiona, and Grant Banfield. 2019. "Using Bourdieu to Understand the Pathways to Belonging That Are Forged by Young Students of Refugee Experience in an Australian Mainstream School.” In Habib and Ward 2019a: 105-122.

Robb, Martin, Brid Featherstone, Sandy Ruxton, and Michael R. M. Ward. 2015. "Beyond Male Role Models: Gender Identities and Work with Young Men." An Open University research project working with Action for Children. Funded by the Economic and Social Research Council (grant no. $\mathrm{ES} / \mathrm{K} 005863 / 1)$.

Roberts, Steven. 2013. "Boys Will Be Boys ... Won't They? Change and Continuities in Contemporary Young Working-Class Masculinities.” Sociology 47 (4): 671-686.

Roberts, Steven, ed. 2014. Debating Modern Masculinities, Change, Continuity Crisis? London: Palgrave MacMillan.

Tarrant, Anna, Gareth Terry, Michael R. M. Ward, Sandy Ruxton, Martin Robb, and Brid Featherstone. 2015. "Are Male Role Models Really the Solution? Interrogating the 'War on Boys' through the Lens of the 'Male Role Model' Discourse." Boyhood Studies 8 (1): 60-83.

Thurnell-Read, Thomas. 2012. "What Happens on Tour: The Premarital Stag Tour, Homosocial Bonding, and Male Friendship." Men and Masculinities 15 (3): 249-270.

Thurnell-Read, Thomas. 2016. "Masculinity, Age and Rapport in Qualitative Research." In Gender Identity and Research Relationships, ed. Michael R. M. Ward, 23-41. Bingley: Emerald.

Waller, Richard, Nicola Ingram, and Michael R. M. Ward, eds. 2018. Higher Education and Social Inequality: University Admissions, Experiences and Outcomes. London: Routledge.

Ward, Michael R. M. 2015. From Labouring to Learning: Working-Class Masculinities, Education and De-industrialization. London: Palgrave Macmillan.

Ward, Michael R. M. 2019. "(Un)belonging in Higher Education: Negotiating Working-Class Masculinities within and beyond the University Campus.” In Habib and Ward 2019a: 159-176.

Ward, Michael R. M., Anna Tarrant, Gareth Terry, Martin Robb, Brid Featherstone, and Sandy Ruxton. 2017. "Doing Gender Locally: The Importance of 'Place' in Understanding Young Men's Masculinities in the Male Role Model Debate." Sociological Review 65 (4): 797-815. 
Walker, Charlie, and Steven Roberts, eds. 2018. Masculinity, Labour and Neoliberalism: Working-Class Men in International Perspective. London: Palgrave Macmillan.

Wignall, Ross. 2019. "Belonging without Believing? Making Space for Marginal Masculinities at the Young Men's Christian Association in the United Kingdom and the Gambia." In Habib and Ward 2019b: 109-121. 